\title{
SISTEM PENDUKUNG KEPUTUSAN PEMILIHAN KARYAWAN BERPRESTASI DENGAN METODE ANALYTIC HIERARCHY PROCESS (Studi Kasus: Divisi Antaran PT. Pos Indonesia MPC Banjarmasin)
}

\author{
Rizki Basriani ${ }^{1}$, Gunawan ${ }^{2}$
}

1. Pendidikan Teknologi Informasi STKIP PGRI Banjarmasin basrianirizki@gmail.com,

2. Pendidikan Teknologi Informasi STKIP PGRI Banjarmasin gunawan@stkipbjm.ac.id.

\begin{abstract}
ABSTRAK
Penentuan karyawan berprestasi pada PT. Pos Indonesia MPC Banjarmasin, khususnya Divisi Antaran dilakukan berdasarkan kriteria yang sudah ditentukan. Permasalahan yang dihadapi pada Divisi Antaran PT. Pos Indonesia MPC Banjarmasin adalah bagaimana menentukan karyawan berprestasi dari sejumlah alternatif (karyawan) dengan memperhatikan tingkat kepentingan dari sejumlah tujuan atau kriteria yang telah ditentukan. Untuk itu, dibangun Sistem Pendukung Keputusan (SPK) Pemilihan Karyawan Berprestasi dengan metode Analityc Hierarchy Process (AHP) sehingga membantu manajer untuk menentukan karyawan berprestasi pada Divisi Antaran PT. Pos Indonesia MPC Banjarmasin. Sistem ini dibangun dengan menggunakan bahasa pemrograman PHP dan basis data MySQL.
\end{abstract}

Kata Kunci: Sistem Pendukung Keputusan, Pemilihan Karyawan Berprestasi, AHP

\section{PENDAHULUAN}

\section{A. Latar Belakang Masalah}

Pada era globalisasi seperti sekarang ini, persaingan perusahaanperusahaan baik yang bergerak di bidang penjualan barang ataupun yang bergerak di bidang pelayanan jasa sangat pesat. Persaingan antar perusahaan tersebut terjadi mulai dari perusahaan kecil, menengah atau bahkan perusahaan besar. Untuk mengatasi pesatnya persaingan antar perusahaan tersebut, khususnya perusahaan yang bergerak di bidang jasa, maka seluruh karyawan dalam perusahaan tersebut harus menunjukkan kinerja yang maksimal.

PT. Pos Indonesia MPC Banjarmasin adalah Badan Usaha Milik Negara (BUMN) yang bergerak di bidang pos yang memberikan pelayanan jasa dengan cakupan nasional dan internasional. Setiap karyawan dituntut untuk dapat bekerja sesuai tugas pokok dan fungsinya dengan baik sehingga mampu meningkatkan prestasi bekerja mereka. Dalam melaksanakan operasional perusahaan, PT. Pos Indonesia MPC Banjarmasin memilih karyawan berprestasi di tiap bagian bidang kerjanya.Karyawan yang terpilih menjadi karyawan berprestasi diberikan penghargaan. Dengan adanya penghargaan tersebut, karyawan dapat lebih semangat dalam bekerja. 
Berdasarkan surat edaran Nomor: SE 56/DIR SDM/0704 lampiran 4 menurut keputusan Direksi PT. Pos Indonesia (Persero) Nomor 120/DIRUT/1999 tentang Memberikan Penghargaan Prestasi Kerja terhadap Karyawan PT. Pos Indonesia (Persero). Di PT. Pos Indonesia MPC Banjarmasin terdapat beberapa faktor yang menjadi penilaian. Demi efisiensi dan efektivitas kerja maka pengambilan keputusan yang tepat sangat diperlukan. Dalam mengambil keputusan terhadap pemilihan karyawan berprestasi, PT. Pos Indonesia MPC Banjarmasin masih menerapkan cara yang sederhana yaitu dengan memberikan nilai pada tiap kriteria dan hasilnya adalah penjumlahan nilai dari tiap kriteria tersebut. Hasil penjumlahan yang tertinggi yang mendapatkan penghargaan sebagai karyawan berprestasi.

Dengan menggunakan cara tersebut maka pimpinan sulit dan terkadang salah dalam melakukan perhitungan untuk menentukan karyawan mana yang berprestasi. Hal ini diakibatkan karena banyaknya jumlah karyawan dan kriteria yang ditetapkan untuk memilih karyawan berprestasi. Selain itu, tingkat kepentingan atau bobot kriteria yang satu dengan kriteria yang lain diabaikan. Untuk mengatasi permasalahan di atas, maka perlu dibangun suatu sistem pendukung keputusan untuk mempermudah menentukan karyawan berprestasi dengan menggunakan metode Analytic Hierarchy Process (AHP).

\section{METODE}

\section{Sistem Pendukung Keputusan (SPK)}

Sistem pendukung keputusan (SPK) adalah sistem informasi berbasis komputer yang dirancang sedemikian rupa sehingga membantu manajer untuk memilih salah satu dari banyak solusi alternatif untuk suatu masalah. Hal ini dimungkinkan untuk mengotomatisasi beberapa proses pengambilan keputusan dengan SPK berbasis komputer yang canggih dan menganalisis sejumlah besar informasi dengan cepat. Ini membantu perusahaan untuk meningkatkan pangsa pasar, mengurangi biaya, meningkatkan profitabilitas dan meningkatkan kualitas [1].

Sistem pendukung keputusan juga bisa didefinisikan sebagai sistem informasi berbasis komputer yang interaktif, fleksibel, dan dapat disesuaikan, yang memanfaatkan aturan-aturan keputusan, model, dan basis model yang digabungkan dengan basis data yang komprehensif dan pemahaman dari pembuat keputusan sendiri, yang mengarah pada keputusan spesifik yang diimplementasikan dalam memecahkan masalah. Dengan demikian, sistem pendukung keputusan mendukung pengambilan keputusan yang kompleks dan meningkatkan efektivitas [1].

\section{Analytic Hierarchy Process (AHP)}

Analytic Hierarchy Process (AHP) adalah suatu teori pengukuran melalui perbandingan berpasangan dan bergantung pada penilaian para ahli dalam menentukan skala prioritas. Perbandingan dibuat dengan menggunakan skala penilaian yang mewakili seberapa besar satu elemen mendominasi lain sehubungan dengan atribut tertentu. Penilaian mungkin tidak konsisten. Oleh karena itu, perlu dilakukan suatu perhitungan untuk mendapatkan konsistensi yang lebih baik [2].

Untuk melihat skala penilaian yang mewakili seberapa besar satu kriteria mendominasi kriteria lain bisa dilihat pada Tabel 1 berikut [3]. 
Tabel 1. Skala Penilaian Perbandingan Berpasangan

\begin{tabular}{cl}
\hline Nilai & \multicolumn{1}{c}{ Interpretasi } \\
\hline 1 & $\begin{array}{l}\boldsymbol{O}_{\boldsymbol{i}} \text { dan } \boldsymbol{O}_{\boldsymbol{j}} \text { sama penting } \\
\boldsymbol{O}_{\boldsymbol{i}} \text { sedikit lebih penting } \\
\text { daripada } \boldsymbol{O}_{\boldsymbol{j}}\end{array}$ \\
5 & $\begin{array}{l}\boldsymbol{O}_{\boldsymbol{i}} \text { kuat tingkat } \\
\text { kepentingannya daripada } \boldsymbol{O}_{\boldsymbol{j}} \\
\boldsymbol{O}_{\boldsymbol{i}} \text { sangat kuat tingkat } \\
\text { kepentingannya daripada } \boldsymbol{O}_{\boldsymbol{j}} \\
\boldsymbol{O}_{\boldsymbol{i}} \text { mutlak lebih penting } \\
\text { daripada } \boldsymbol{O}_{\boldsymbol{j}}\end{array}$ \\
$2,4,6,8$ & Nilai-nilai intermediate \\
\hline
\end{tabular}

Langkah-langkah penyelesaian masalah dengan metode AHP sebagai berikut [3]: Langkah Pertama

Melakukan agregasi terhadap keputusan-keputusan yang tanggap terhadap semua tujuan pada setiap alternatif. Langkah-langkahnya yaitu sebagai berikut:

a. Menentukan matriks perbandingan berpasangan. Matriks perbandingan berpasangan adalah matriks berukuran $n \times n$ dengan elemen $a_{i j}$ merupakan nilai relatif tujuan ke- $i$ terhadap tujuan ke-j. Matriks perbandingan berpasangan dikatakan konsisten jika dan hanya jika untuk setiap $i, j$, dan $k \neq i \in\{1,2, \ldots, n\}$ berlaku:

$$
\begin{gathered}
a_{i i}=1 ; \\
a_{i j}=\frac{1}{a_{j i}} ; \\
a_{i k}=\left(a_{i j}\right)\left(a_{j k}\right) .
\end{gathered}
$$

b. Apabila A adalah matriks perbandingan berpasangan yang tidak konsisten, maka dapat didekati dengan cara:

(i) Menormalkan setiap kolom j dalam matriks A sedemikian hingga:

sebut sebagai A'.

$$
\sum_{i} a_{i j}=1
$$

(ii) Menentukan nilai rata-rata untuk setiap baris $i$ dalam A' yaitu:

$$
w_{i}=\frac{1}{n} \sum_{i} a_{i j}
$$

dengan $w_{i}$ adalah bobot tujuan ke-i dari vektor bobot.

c. Menguji konsistensi matriks A dengan cara:

- Hitung: (A) $\left(w^{t}\right)$

- Hitung : $t=\frac{1}{n} \sum_{i=1}^{n} \frac{\text { elemen ke- } i \text { pada }(\mathrm{A})\left(w^{t}\right)}{\text { elemen ke- } i \text { pada } w^{t}}$

- Hitung indeks konsistensi/ Consistency Index (CI)

$$
C I=\frac{t-n}{n-1}
$$

- Hitung rasio konsistensi/ Consistency Ratio (CR) 


$$
C R=\frac{C I}{R I_{n}}
$$

Jika $C R=0$ maka A konsisten; jika $C R \leq 0,1$ maka A cukup konsisten; dan jika $C R>0,1$ maka A sangat tidak konsisten.

Indeks random $R I_{n}$ adalah nilai rata-rata $C I$ yang dipilih secara acak pada A, bisa dilihat pada Tabel 2 berikut [3, 4]:

\begin{tabular}{cc} 
Tabel 2. Daftar Indeks Random \\
\hline \multicolumn{2}{c}{$\boldsymbol{R}_{\boldsymbol{n}}$} \\
\hline 2 & 0 \\
3 & 0,58 \\
4 & 0,90 \\
5 & 1,12 \\
6 & 1,24 \\
7 & 1,32 \\
8 & 1,41 \\
9 & 1,45 \\
10 & 1,49 \\
\hline
\end{tabular}

Langkah Kedua

Melakukan pemeringkatan alternatif-alternatif keputusan tersebut berdasarkan hasil agregasi keputusan. Misalkan ada $n$ tujuan dan $m$ alternatif, maka proses pemeringkatan alternatif dapat dilakukan melalui langkah-langkah sebagai berikut:

a. Untuk setiap tujuan $i$, menentukan matriks perbandingan berpasangan A, untuk $m$ alternatif.

b. Menentukan vektor bobot untuk setiap $\mathrm{A}_{i}$ yang merepresentasikan bobot relatif dari setiap alternatif ke-j pada tujuan ke-i $\left(s_{i j}\right)$.

c. Hitung total skor:

$$
s_{j}=\sum_{i}\left(s_{i j}\right)\left(w_{i}\right)
$$

d. Pilih alternatif dengan skor tertinggi.

\section{Analisis dan Desain Sistem}

Kriteria pemilihan karyawan berprestasi di PT. Pos Indonesia MPC Banjarmasin yaitu: (1) Paham Ketentuan Tentang Mengantar, (2) Kinerja Antaran Kiriman, (3) Kesesuaian DO Dengan Fisik, (4) Clean Floor (Kiriman Diantar Habis), (5) Tidak Berhasil Antar Untuk Antaran Besok, (6) Gagal Antar Kemsip, (7) Mutu Update Status, (8) Kiriman Terbuka (Inproses), (9) Komplain Pelanggan, (10) Tampilan, Kerapihan dan Ketepatan Berangkat Mengantar. Sedangkan kriteria untuk memilih mandor berprestasi divisi antaran di PT. Pos Indonesia MPC Banjarmasin yaitu, (1) Pemahaman SOP Antaran, (2) Kesesuaian DO Dengan Fisik, (3) Clean Floor (Kiriman Diantar Habis), (4) Mutu Update Status, (5) Uji Petik Kiriman Gagal, (6) Uji Petik Antaran, (7) Penanganan ADM Kiriman Return, (8) Kiriman Terbuka/Inproses, (9) Komplain Pelanggan, (10) Kerapihan dan Ketepatan Adm Neraca. Kriteria ini didapat berdasarkan wawancara dengan manajer antaran dan berdasarkan surat edaran Nomor: SE 56/DIR SDM/0704 lampiran 4 menurut keputusan Direksi PT. Pos Indonesia (Persero) Nomor 120/DIRUT/1999 tentang 
Memberikan Penghargaan Prestasi Kerja terhadap karyawan PT. Pos Indonesia (Persero).

\section{Hirarki}

Informasi mengenai sasaran, kriteria dan alternatif tersebut disusun dalam bentuk diagram bertingkat/ hierarki seperti yang terlihat pada Gambar 1 berikut:

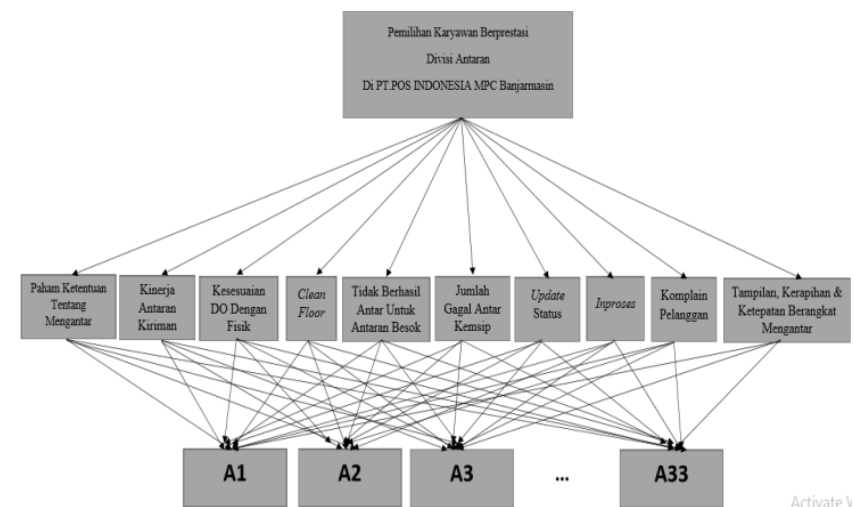

Gambar 1. Diagram Bertingkat Pemilihan Karyawan Berprestasi

\section{Flowchart}

Adapun perhitungan AHP dalam pemilihan karyawan berprestasi berupa flowchart seperti Gambar 2 berikut:

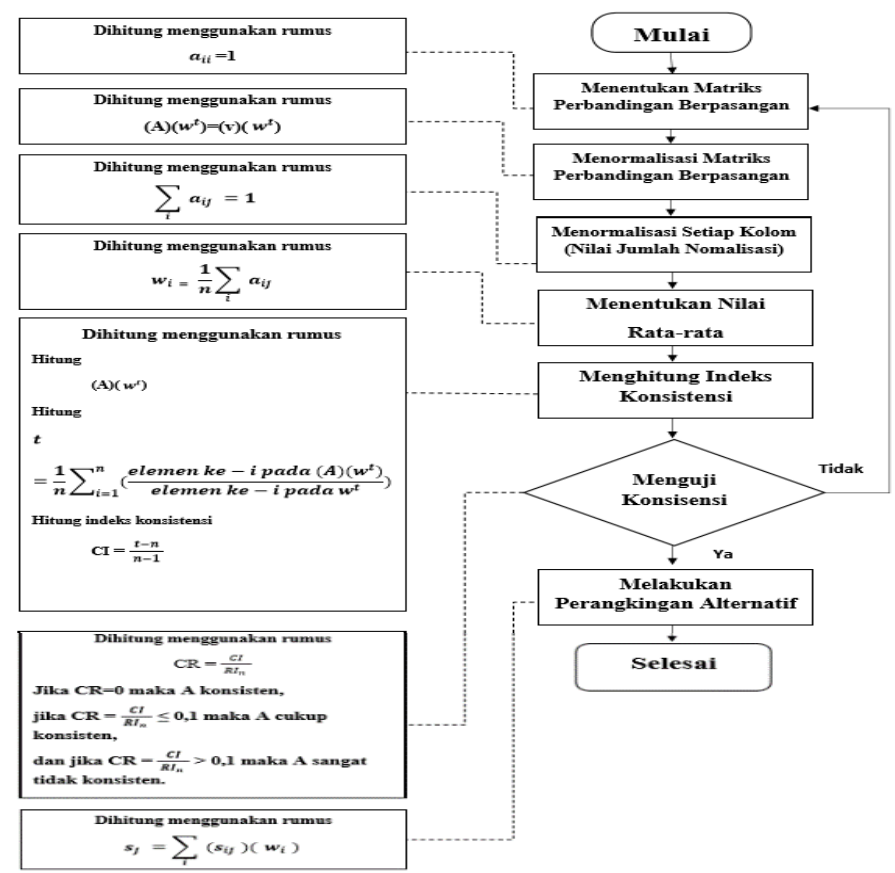

Gambar 2. Flowchart Pemilihan Karyawan Berprestasi 


\section{Entity Relationship Diagram (ERD)}

ERD (Entity Relationship Diagram) adalah suatu model untuk menjelaskan hubungan natar data berdasarkan objek-objek dasar data yang mempunyai hubungan antar relasi, ERD untuk memodelkan struktur data dan hubungan antar data. ERD pemilihan karyawan berprestasi digambarkan seperti Gambar 3 berikut:

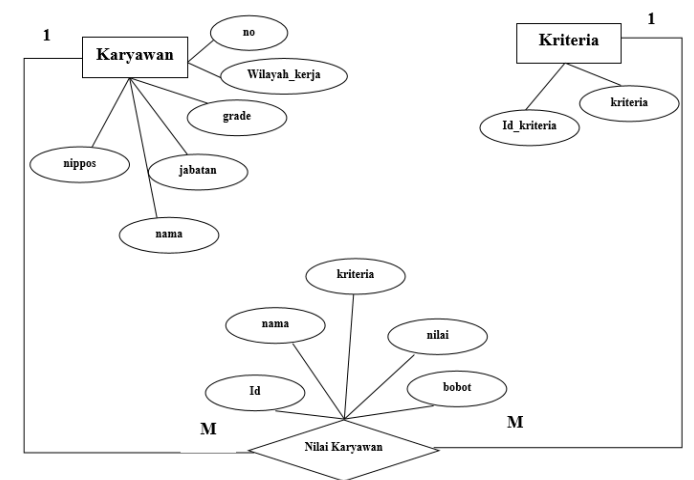

Gambar 3. Entity Relationship Diagram (ERD) Pemilihan Karyawan Berprestasi

\section{Workflow}

Alur pemilihan karyawan berprestasi Divisi Antaran PT. Pos Indonesia MPC Banjarmasin digambarkan dalam workflow disajikan pada Gambar 4:

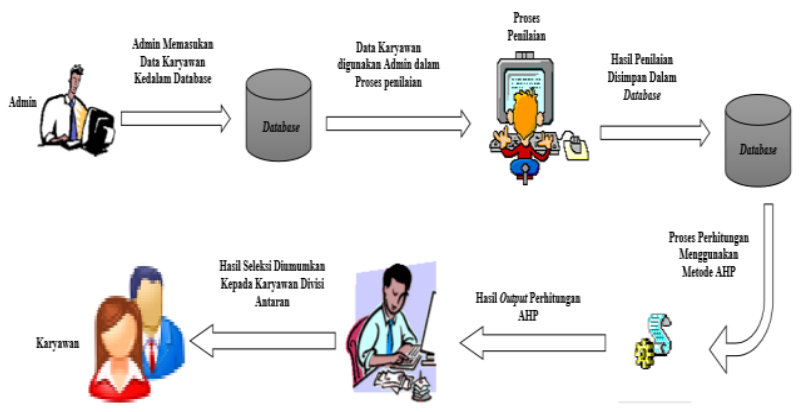

Gambar 4. Workflow Pemilihan Karyawan Berprestasi

\section{HASIL DAN PEMBAHASAN}

\section{Pemilihan Pengantar Surat Berprestasi}

Kriteria untuk memilih pengantar surat berprestasi Divisi Antaran PT. Pos Indonesia MPC Banjarmasin di dapat dari hasil wawancara langsung dengan pihak Manajer Antaran yaitu: (1) Paham Ketentuan Tentang Mengantar, (2) Kinerja Antaran Kiriman, (3) Kesesuaian DO Dengan Fisik, (4) Clean Floor (Kiriman Diantar Habis), (5) Tidak Berhasil Antar Untuk Antaran Besok, (6) Gagal Antar Kemsip. (7) Mutu Update Status, (8) Kiriman Terbuka (Inproses), (9) Komplain Pelanggan, (10) Tampilan, Kerapihan, dan Ketepatan Berangkat Mengantar. 
Sistem Pendukung Keputusan Pemilihan Karyawan Berprestasi Dengan

Metode Analytic Hierarchy Process (AHP)

\begin{tabular}{cl}
\hline Kode & \multicolumn{1}{c}{ Kriteria } \\
\hline C1 & $\begin{array}{l}\text { Paham Ketentuan Tentang } \\
\text { Mengantar }\end{array}$ \\
C2 & $\begin{array}{l}\text { Kinerja Antaran Kiriman } \\
\text { C3 }\end{array}$ \\
& Kesesuaian DO Dengan \\
& Fisik \\
C4 & Clean Floor (Kiriman \\
& Diantar Habis) \\
C5 & Tidak Berhasil Antar Untuk \\
& Antaran Besok \\
C6 & Gagal Antar Kemsip. \\
C7 & Mutu Update Status \\
C8 & Kiriman Terbuka (Inproses) \\
C9 & Komplain Pelanggan \\
C10 & Tampilan, Kerapihan \& \\
& Ketepatan Berangkat \\
& Mengantar \\
\hline
\end{tabular}

Proses perhitungan pada sistem pendukung keputusan pemilihan karyawan berprestasi Divisi Antaran PT. Pos Indonesia MPC Banjarmasin yaitu sebagai berikut:

1. Melakukan perhitungan terhadap keputusan-keputusan setiap kriteria yaitu:

a. Menentukan matriks perbandingan berpasangan.

Matriks perbandingan berpasangan setiap kriteria ini ditentukan dari hasil angket dengan Manajer Antaran.

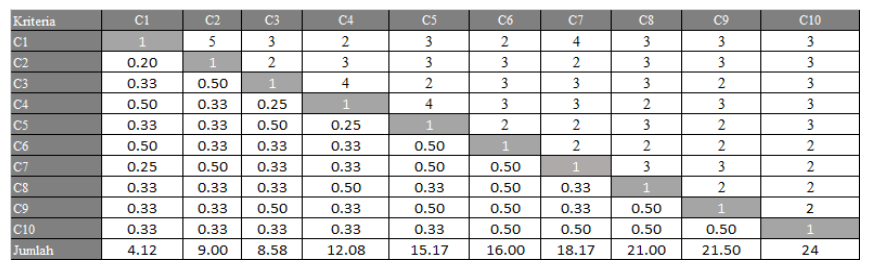

Gambar 5. Matriks Perbandingan Berpasangan Kriteria

b. Matriks perbandingan berpasangan (normalisasi)

\begin{tabular}{l|c|c|c|c|c|c|c|c|c|c} 
Kniteria & $C 1$ & $C 2$ & $C 3$ & $C 4$ & $C 5$ & $C 6$ & $C 7$ & $C 8$ & $C 9$ & $C 10$ \\
\hline$C 1$ & 0.24 & 0.56 & 0.35 & 0.17 & 0.20 & 0.13 & 0.22 & 0.14 & 0.14 & 0.13 \\
\hline$C 2$ & 0.05 & 0.11 & 0.23 & 0.25 & 0.20 & 0.19 & 0.11 & 0.14 & 0.14 & 0.13 \\
\hline$C 3$ & 0.08 & 0.06 & 0.12 & 0.33 & 0.13 & 0.19 & 0.17 & 0.14 & 0.09 & 0.13 \\
\hline$C 4$ & 0.12 & 0.04 & 0.03 & 0.08 & 0.26 & 0.19 & 0.17 & 0.10 & 0.14 & 0.13 \\
\hline$C 5$ & 0.08 & 0.04 & 0.06 & 0.02 & 0.07 & 0.13 & 0.11 & 0.14 & 0.09 & 0.13 \\
\hline$C 6$ & 0.12 & 0.04 & 0.04 & 0.03 & 0.03 & 0.06 & 0.11 & 0.10 & 0.09 & 0.08 \\
\hline$C 7$ & 0.06 & 0.06 & 0.04 & 0.03 & 0.03 & 0.03 & 0.06 & 0.14 & 0.14 & 0.08 \\
\hline$C 8$ & 0.08 & 0.04 & 0.04 & 0.04 & 0.02 & 0.03 & 0.02 & 0.05 & 0.09 & 0.08 \\
\hline$C 9$ & 0.08 & 0.04 & 0.06 & 0.03 & 0.03 & 0.03 & 0.02 & 0.02 & 0.05 & 0.08 \\
\hline$C 10$ & 0.08 & 0.04 & 0.04 & 0.03 & 0.02 & 0.03 & 0.03 & 0.02 & 0.02 & 0.04
\end{tabular}

Gambar 6. Matriks Perbandingan Berpasangan Kriteria (Normalisasi)

c. Menormalkan setiap kolom (nilai jumlah normalisasi)

\begin{tabular}{|c|c|c|c|c|c|c|c|c|c|c|}
\hline Kriteria & $\mathrm{Cl}$ & $\mathrm{C} 2_{2}$ & C3 & C4 & C5 & $\mathrm{C} 6$ & $\mathrm{C} 7$ & C8 & $\mathrm{Cg}$ & $\mathrm{C} 10$ \\
\hline $\mathrm{Cl}$ & 0.24 & 0.56 & 0.35 & 0.17 & 0.20 & 0.13 & 0.22 & 0.14 & 0.14 & 0.13 \\
\hline C2 & 0.05 & 0.11 & 0.23 & 0.25 & 0.20 & 0.19 & 0.11 & 0.14 & 0.14 & 0.13 \\
\hline $\mathrm{CB}$ & 0.08 & 0.06 & 0.12 & 0.33 & 0.13 & 0.19 & 0.17 & 0.14 & 0.09 & 0.13 \\
\hline $\mathrm{C4}$ & 0.12 & 0.04 & 0.03 & 0.08 & 0.26 & 0.19 & 0.17 & 0.10 & 0.14 & 0.13 \\
\hline $\mathrm{C5}$ & 0.08 & 0.04 & 0.06 & 0.02 & 0.07 & 0.13 & 0.11 & 0.14 & 0.09 & 0.13 \\
\hline C6 & 0.12 & 0.04 & 0.04 & 0.03 & 0.03 & 0.06 & 0.11 & 0.10 & 0.09 & 0.08 \\
\hline C7 & 0.06 & 0.06 & 0.04 & 0.03 & 0.03 & 0.03 & 0.06 & 0.14 & 0.14 & 0.08 \\
\hline C8 & 0.08 & 0.04 & 0.04 & 0.04 & 0.02 & 0.03 & 0.02 & 0.05 & 0.09 & 0.08 \\
\hline c9 & 0.08 & 0.04 & 0.06 & 0.03 & 0.03 & 0.03 & 0.02 & 0.02 & 0.05 & 0.08 \\
\hline $\mathrm{C} 10$ & 0.08 & 0.04 & 0.04 & 0.03 & 0.02 & 0.03 & 0.03 & 0.02 & 0.02 & 0.04 \\
\hline Jumlah & & & & & & & & & & \\
\hline
\end{tabular}

Gambar 7 Menormalkan Setiap Kolom 
Basrian, Rizki \& Gunawan/ LENTERA Jurnal Ilmiah Kependidikan Vol. 14 No.2 (Juli - Desember 2019 Edisi Dies Natalis XXXIV) 121-135

d. Menentukan nilai rata-rata

Tabel 4. Rata-rata atau Bobot

\begin{tabular}{ccc} 
Kriteria & Bobot & \\
\cline { 1 - 2 } C1 & 0,226 & \\
C2 & 0,154 \\
C3 & 0,143 \\
C4 & 0,125 \\
C5 & 0,086 \\
C6 & 0,070 & \\
C7 & 0,067 & \\
C8 & 0,049 & \\
C9 & 0,044 & konsistensi \\
C10 & 0,035 & \\
\hline
\end{tabular}

\begin{tabular}{|c|c|}
\hline Kriteria & Uji Bobot \\
\hline $\mathrm{C} 1$ & 2,728 \\
\hline $\mathrm{C} 2$ & 1,848 \\
\hline $\mathrm{C} 3$ & 1,719 \\
\hline $\mathrm{C} 4$ & 1,416 \\
\hline $\mathrm{C} 5$ & 0,932 \\
\hline C6 & 0,758 \\
\hline C7 & 0,719 \\
\hline C8 & 0,531 \\
\hline C9 & 0,480 \\
\hline $\mathrm{C} 10$ & 0,395 \\
\hline
\end{tabular}

- Menghitung $t$

$$
\begin{aligned}
t=\frac{1}{10}\left(\frac{2,728}{0,226}+\frac{1,848}{0,154}+\frac{1,719}{0,143}\right. \\
+\frac{1,416}{0,125}+\frac{0,932}{0,086}+\frac{0,758}{0,070} \\
+\frac{0,719}{0,067}+\frac{0,531}{0,049}+\frac{0,480}{0,044} \\
\left.+\frac{0,395}{0,035}\right)=11,265
\end{aligned}
$$

- Menghitung indeks konsistensi

$$
\mathrm{CI}=\frac{11,265-10}{10-1}=0,141
$$

Juga karena $n=10$, maka berdasarkan Tabel 2 diperoleh $R I_{10}=1,49$ sehingga $C R=\frac{C I}{R I_{10}}=\frac{0,141}{1,49}=0,094$ karena $0,094 \leq 0,1$, maka matriks dikatakan cukup konsisten.

2. Melakukan pemeringkatan alternatif-alternatif keputusan tersebut berdasarkan hasil agregasi keputusan.

a. Menentukan matriks perbandingan berpasangan setiap alternatif 
Menghitung alternatif (peserta) yang akan dipilih terhadap kriteria-kriteria, dimisalkan data yang diperoleh seperti Gambar 8 berikut:

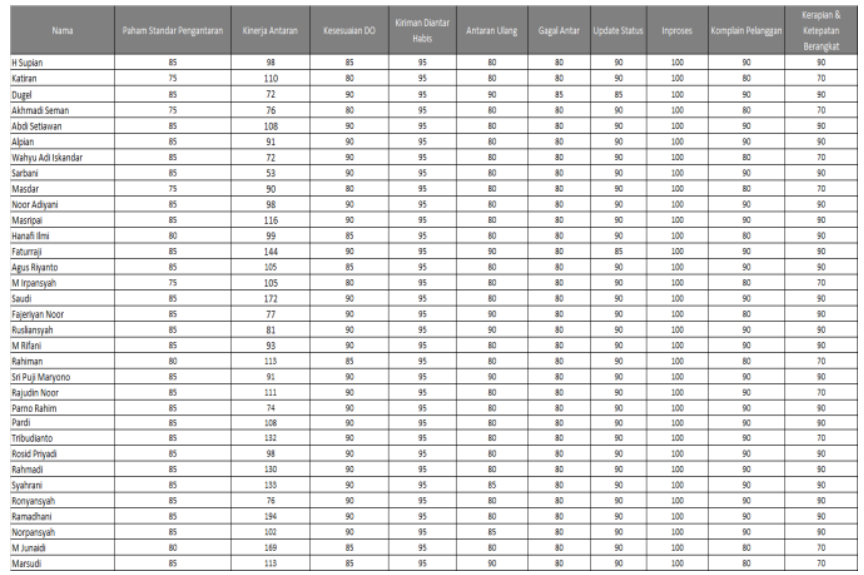

Gambar 8 Daftar Hasil

b. Menentukan vektor bobot (rata-rata) dari setiap alternatif.

Matriks skor setiap alternatif pada semua kriteria adalah seperti Gambar 9 berikut:

\begin{tabular}{|c|c|c|c|c|c|c|c|c|c|c|c|c|c|c|c|}
\hline & \\
\hline & & $\square b$ & 4 & & H: & \& & All & & L. 41. & & & & II All & & 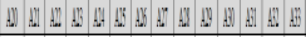 \\
\hline & & 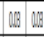 & $18 \mathrm{at}$ & 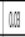 & & III 18 & 3 & & 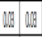 & & & & IIB $1 \mathrm{BS}$ & II & 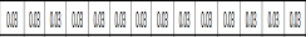 \\
\hline & & 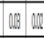 & $(10)$ & 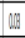 & $\Delta \mathrm{MBO}$ & III UIS & & & Lig & ㄴ. & (1:32 & & II: 12 & IIB & 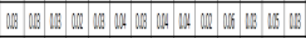 \\
\hline & & LIS 10 & at $a x$ & 187 & als 18 & II $1 \mathrm{BS}$ & & & 18. 때 & OM & als & & II $\triangle 1 \mathrm{~B}$ & & 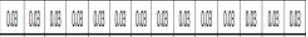 \\
\hline & & a. 14 & 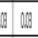 & 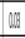 & Ma 18 & IIS IIS & 3 & & 198 & ald & als & & LIB $1 \mathrm{~B}$ & II & 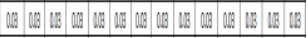 \\
\hline & & 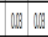 & 18 & (19: & & IIB 18 & 3 ㄴ. & & 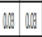 & 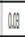 & Q1S & & UIB $1 \mathrm{BB}$ & H: & 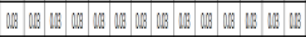 \\
\hline & & LIS 10. & 政 & & ㄴ. & $18 \mathbb{1 B}$ & 18 & & (ID 10 & 내은 & a. & & LIB $1 \mathrm{~B}$ & & 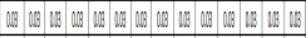 \\
\hline & & 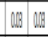 & (n) & & & $18 \mathbb{B S}$ & & & 18 & $\mathrm{~m}$ & W & & 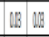 & & 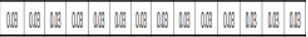 \\
\hline & & MIS & (1) & & aIB 18 & III UB & & & LIA 14 & & & & LB $1 \mathrm{BB}$ & & 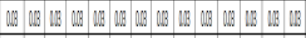 \\
\hline & & 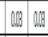 & (1) 108 & & a. 18 & IIS 18 & & & 내은 & & & & 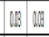 & & 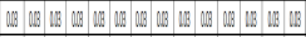 \\
\hline & & 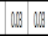 & & & & & & & & & & & & & 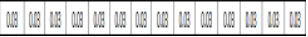 \\
\hline
\end{tabular}

Gambar 9 Matriks skor total

c. Hitung Total Skor

Vektor bobot yang diperoleh sebelumnya adalah $w=[0,226 ; 0,154 ; 0,143 ; 0,125$; 0,086; 0,070; 0,067; 0,049; 0,044; 0,035 ]

Skor total setiap alternatif adalah

$$
\begin{aligned}
s_{1}= & (0,031)(0,226)+(0,028)(0,154)+(0,029)(0,143)+(0,030)(0,125)+ \\
& (0,030)(0,086)+(0,030)(0,070)+(0,030)(0,067)+(0,030)(0,049)+ \\
& (0,031)(0,044)+(0,033)(0,035)=\mathbf{0 , 0 3 0 0} \\
s_{2}= & (0,027)(0,226)+(0,031)(0,154)+(0,028)(0,143)+(0,030)(0,125)+ \\
& (0,030)(0,086)+(0,030)(0,070)+(0,030)(0,067)+(0,030)(0,049)+ \\
& (0,028)(0,044)+(0,026)(0,035)=\mathbf{0 , 0 2 9 0} \\
\cdots \quad & (0,031)(0,226)+(0,055)(0,154)+(0,031)(0,143)+(0,030)(0,125)+ \\
s_{30}= & (0,030)(0,086)+(0,030)(0,070)+(0,030)(0,067)+(0,030)(0,049)+ \\
& (0,031)(0,044)+(0,033)(0,035)=\mathbf{0 , 0 3 4 5}
\end{aligned}
$$




$$
\begin{aligned}
s_{33}= & (0,031)(0,226)+(0,032)(0,154)+(0,029)(0,143)+(0,030)(0,125)+ \\
& (0,033)(0,086)+(0,030)(0,070)+(0,030)(0,067)+(0,030)(0,049)+ \\
& (0,028)(0,044)+(0,025)(0,035)=\mathbf{0 , 0 3 0 6}
\end{aligned}
$$

d. Menentukan alternatif skor

Karena skor total A30 paling tinggi, maka alternatif A30 yang dipilih.

\section{Pemilihan Mandor Berprestasi}

Kriteria untuk memilih mandor berprestasi divisi antaran di PT. Pos Indonesia MPC Banjarmasin di dapat dari hasil wawancara langsung dengan pihak Manajer Antaran yaitu: (1) Pemahaman SOP Antaran, (2) Kesesuaian DO dengan Fisik, (3) Clean Floor (Kiriman Diantar Habis), (4) Mutu Update Status, (5) Uji Petik Kiriman Gagal, (6) Uji Petik Antaran, (7) Penanganan ADM Kiriman Return, (8) Kiriman Terbuka (Inproses), (9) Komplain Pelanggan, (10) Kerapihan dan Ketepatan Adm Neraca.

Tabel 6 Kode dan Kriteria Mandor

\begin{tabular}{cl}
\hline Kode & \multicolumn{1}{c}{ Kriteria } \\
\hline C1 & Pemahaman SOP Antaran \\
C2 & Kesesuaian DO dengan Fisik \\
C3 & Clean Floor (Kiriman Diantar \\
& Habis) \\
C4 & Mutu Update Status \\
C5 & Uji Petik Kiriman Gagal Antar \\
C6 & Uji Petik Antaran \\
C7 & Penanganan ADM Kiriman \\
& Return \\
C8 & Kiriman Terbuka (Inproses) \\
C9 & Komplain Pelanggan \\
C10 & Kerapihan dan Ketepatan Adm \\
& Neraca \\
\hline
\end{tabular}

Proses perhitungan pada sistem pendukung keputusan pemilihan karyawan berprestasi Divisi Antaran PT. Pos Indonesia MPC Banjarmasin yaitu sebagai berikut:

1. Melakukan perhitungan terhadap keputusan-keputusan setiap kriteria yaitu:

a. Menentukan matriks perbandingan berpasangan

Menentukan matriks perbandingan berpasangan setiap kriteria ini ditentukan dari hasil angket dengan Manajer Antaran.

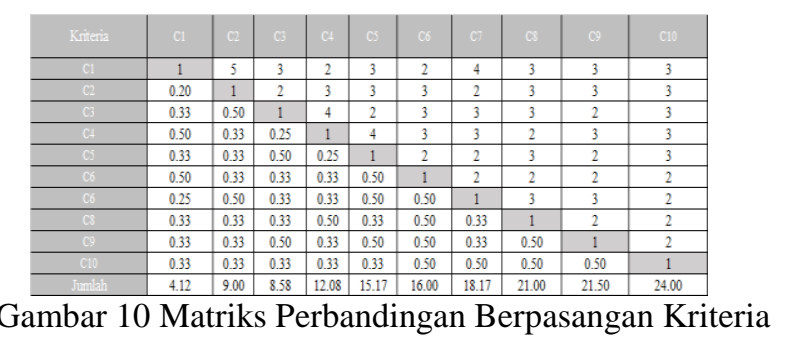


b. Matriks perbandingan berpasangan (normalisasi)

\begin{tabular}{|c|c|c|c|c|c|c|c|c|c|c|}
\hline Kriteis & OI & c. & C5 & ct & Cs & 06 & c) & c8 & 02 & 010 \\
\hline 01 & 0.24 & 0.56 & 0.35 & 0.17 & 0.20 & 0.13 & 0.22 & 0.14 & 0.14 & 0.13 \\
\hline 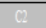 & 0.05 & 0.11 & 0.23 & 0.25 & 0.20 & 0.19 & 0.11 & 0.14 & 0.14 & 0.13 \\
\hline 18 & 0.08 & 0.06 & 0.12 & 0.33 & 0.13 & 0.19 & 0.17 & 0.14 & 0.09 & 0.13 \\
\hline $\mathrm{CH}$ & 0.12 & 0.04 & 0.03 & 0.08 & 0.26 & 0.19 & 0.17 & 0.10 & 0.14 & 0.13 \\
\hline 65 & 0.08 & 0.04 & 0.06 & 0.02 & 0.07 & 0.13 & 0.11 & 0.14 & 0.09 & 0.13 \\
\hline 06 & 0.12 & 0.04 & 0.04 & 0.03 & 0.03 & 0.06 & 0.11 & 0.10 & 0.09 & 0.08 \\
\hline 0 & 0.06 & 0.06 & 0.04 & 0.03 & 0.03 & 0.03 & 0.06 & 0.14 & 0.14 & 0.08 \\
\hline a & 0.08 & 0.04 & 0.04 & 0.04 & 0.02 & 0.03 & 0.02 & 0.05 & 0.09 & 0.08 \\
\hline 0 & 0.08 & 0.04 & 0.06 & 0.03 & 0.03 & 0.03 & 0.02 & 0.02 & 0.05 & 0.08 \\
\hline 010 & 0.08 & 0.04 & 0.04 & 0.03 & 0.02 & 0.03 & 0.03 & 0.02 & 0.02 & 0.04 \\
\hline
\end{tabular}

Gambar 11 Matriks Perbandingan Berpasangan Kriteria (Normalisasi)

c. Menormalkan setiap kolom (nilai jumlah normalisasi)

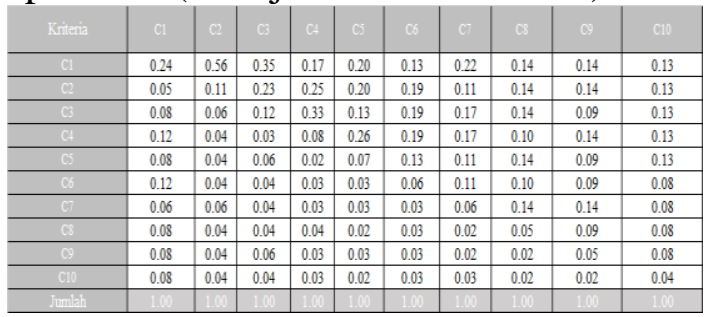

Gambar 12 Menormalkan Setiap Kolom

d. Menentukan nilai rata-rata

$\underline{\text { Tabel 7. Rata-rata atau Bobot }}$

\begin{tabular}{cc}
\hline Kriteria & Bobot \\
\hline C1 & 0,226 \\
C2 & 0,154 \\
C3 & 0,143 \\
C4 & 0,125 \\
C5 & 0,086 \\
C6 & 0,070 \\
C7 & 0,067 \\
C8 & 0,049 \\
C9 & 0,044 \\
C10 & 0,035 \\
\hline
\end{tabular}

e. Menghitung nilai konsistensi mandor

- Menghitung (A)( $\left.w^{t}\right)$

Tabel 8 Pengujian Bobot

\begin{tabular}{cc}
\hline Kriteria & Uji Bobot \\
\hline C1 & 0,269 \\
C2 & 0,148 \\
C3 & 0,136 \\
C4 & 0,110 \\
C5 & 0,072 \\
C6 & 0,069 \\
C7 & 0,056 \\
\hline
\end{tabular}


Basrian, Rizki \& Gunawan/ LENTERA Jurnal Ilmiah Kependidikan Vol. 14 No.2 (Juli - Desember 2019 Edisi Dies Natalis XXXIV) 121-135

\begin{tabular}{cc}
\hline C8 & 0,049 \\
C9 & 0,048 \\
C10 & 0,043 \\
\hline
\end{tabular}

- Menghitung $t$

$$
\begin{gathered}
t=\frac{1}{10}\left(\frac{0,269}{0,226}+\frac{0,148}{0,154}+\frac{0,136}{0,143}\right) \\
+\frac{0,110}{0,125}+\frac{0,072}{0,086}+\frac{0,069}{0,070} \\
+\frac{0,056}{0,067}+\frac{0,049}{0,049}+\frac{0,048}{0,044} \\
\left.+\frac{0,043}{0,035}\right)=0,99
\end{gathered}
$$

- Menghitung indeks konsistensi

$$
\mathrm{CI}=\frac{0,99-10}{10-1}=-1
$$

Juga karena $n=10$, maka berdasarkan Tabel 2 diperoleh $R I_{10}=1,49$ sehingga, $C R=\frac{C I}{R I_{10}}=\frac{-1}{1,49}=-0,67$ karena $-0,67 \leq 0,1$, maka matriks dikatakan cukup konsisten.

2. Melakukan pemeringkatan alternatif-alternatif keputusan tersebut berdasarkan

\begin{tabular}{|c|c|c|c|c|c|c|c|c|c|c|}
\hline \multirow{2}{*}{ Altraif } & \multicolumn{10}{|c|}{ Kitring } \\
\hline & $\mathrm{Cl}$ & C. & $C_{3}$ & $\mathrm{CH}_{\mathrm{C}}$ & $\mathrm{Cs}$ & Co & 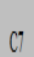 & c \& & 0 & $\mathrm{ClO}$ \\
\hline Bari & 90 & 90 & 80 & 90 & 70 & 70 & 90 & 90 & 85 & 90 \\
\hline Syartidiofin & 70 & 80 & 90 & 80 & 70 & 70 & 85 & 90 & 85 & 85 \\
\hline StantR & 85 & 85 & 80 & 80 & 70 & 70 & 90 & 90 & 80 & 80 \\
\hline Fanir & 85 & 80 & 80 & 90 & 70 & 70 & 80 & 90 & 90 & 85 \\
\hline
\end{tabular}
hasil agregasi keputusan.

a. Menentukan matriks perbandingan berpasangan setiap alternatif.

Menghitung alternatif (peserta) yang akan dipilih berdasarkan kriteria-kriteria. Dimisalkan data yang diperoleh seperti Gambar 13 berikut:

\begin{tabular}{|c|c|c|c|c|c|}
\hline \multirow{2}{*}{ Kriteria } & \multicolumn{4}{|c|}{ Alternatif } & \multirow{2}{*}{ Bobot } \\
\hline & A1 & A2 & A3 & A4 & \\
\hline $\mathrm{C} 1$ & 0.27 & 0.21 & 0.26 & 0.26 & 0.23 \\
\hline $\mathrm{C} 2$ & 0.24 & 0.27 & 0.24 & 0.24 & 0.15 \\
\hline C3 & 0.24 & 0.27 & 0.24 & 0.24 & 0.14 \\
\hline $\mathrm{C} 4$ & 0.26 & 0.24 & 0.24 & 0.26 & 0.12 \\
\hline C5 & 0.25 & 0.25 & 0.25 & 0.25 & 0.09 \\
\hline C6 & 0.25 & 0.25 & 0.25 & 0.25 & 0.07 \\
\hline C7 & 0.26 & 0.25 & 0.26 & 0.23 & 0.07 \\
\hline C8 & 0.25 & 0.25 & 0.25 & 0.25 & 0.05 \\
\hline $\mathrm{C} 9$ & 0.25 & 0.25 & 0.24 & 0.26 & 0.04 \\
\hline $\mathrm{C} 10$ & 0.26 & 0.25 & 0.24 & 0.25 & 0.04 \\
\hline
\end{tabular}

Gambar 13 Daftar Hasil

b. Menentukan vektor bobot (rata-rata) dari setiap alternatif.

Matriks skor setiap alternatif pada semua kriteria adalah seperti Gambar 14 berikut:

Gambar 14 Matriks Skor Total 
c. Hitung Total Skor

Vektor bobot yang diperoleh sebelumnya adalah $w=[0,226 ; 0,154 ; 0,143 ; 0,125$; 0,086; 0,070; 0,067; 0,049; 0,044; 0,035]

Skor total setiap alternatif adalah

$$
\begin{gathered}
s_{1}=(0,2727)(0,2264)+(0,2424)(0,1544)+(0,2424)(0,1429)+(0,2647)(0,1247)+ \\
(0,2500)(0,0859)+(0,2500)(0,0702)+(0,2609)(0,0668)+(0,2500)(0,0494)+ \\
(0,2500)(0,0440)+(0,2647)(0,0354)=\mathbf{0 , 2 5 6 0} \\
s_{2}=(0,2121)(0,2264)+(0,2727)(0,1544)+(0,2727)(0,1429)+(0,2353)(0,1247)+ \\
(0,2500)(0,0859)+(0,2500)(0,0702)+(0,2464)(0,0668)+(0,2500)(0,0494)+ \\
(0,2500)(0,0440)+(0,2500)(0,0354)=\mathbf{0 , 2 4 6 1} \\
s_{3}=(0,2576)(0,2264)+(0,2424)(0,1544)+(0,2424)(0,1429)+(0,2353)(0,1247)+ \\
(0,2500)(0,0859)+(0,2500)(0,0702)+(0,2609)(0,0668)+(0,2500)(0,0494)+ \\
(0,2353)(0,0440)+(0,2353)(0,0354)=\mathbf{0 , 2 4 7 2} \\
s_{4}=(0,2576)(0,2264)+(0,2424)(0,1544)+(0,2424)(0,1429)+(0,2647)(0,1247)+ \\
(0,2500)(0,0859)+(0,2500)(0,0702)+(0,2319)(0,0668)+(0,2500)(0,0494)+ \\
(0,2647)(0,0440)+(0,2500)(0,0354)=\mathbf{0 , 2 5 0 7}
\end{gathered}
$$

d. Menentukan alternatif skor

Karena skor total A1 paling tinggi, maka alternatif A1 yang dipilih.

\section{Implementasi Sistem}

a. Halaman Utama

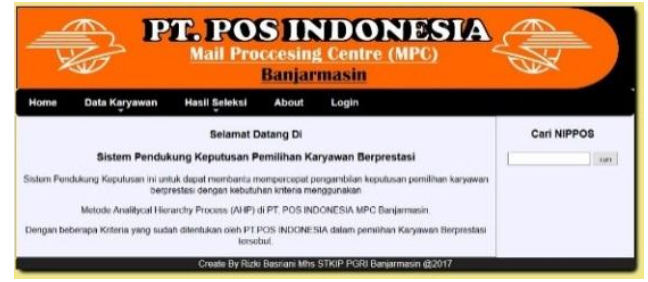

Gambar 14 Halaman Utama

b. Halaman Login

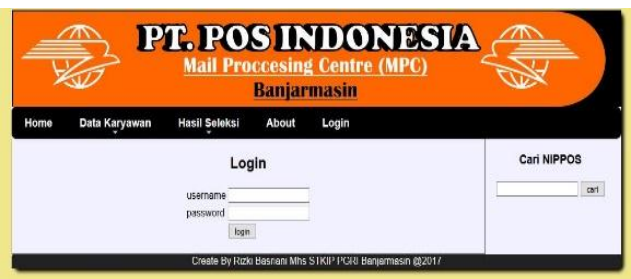

Gambar 15 Halaman Login

c. Halaman Data Karyawan

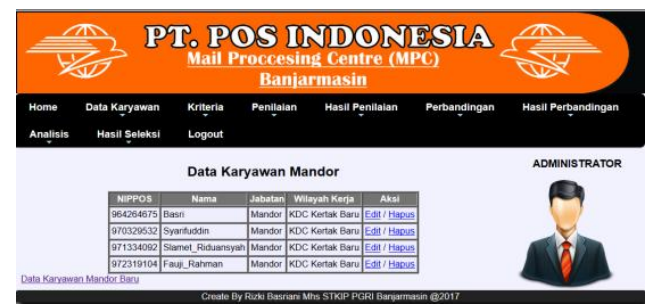

Gambar 16 Halaman Data Karyawan 
d. Halaman Penilaian

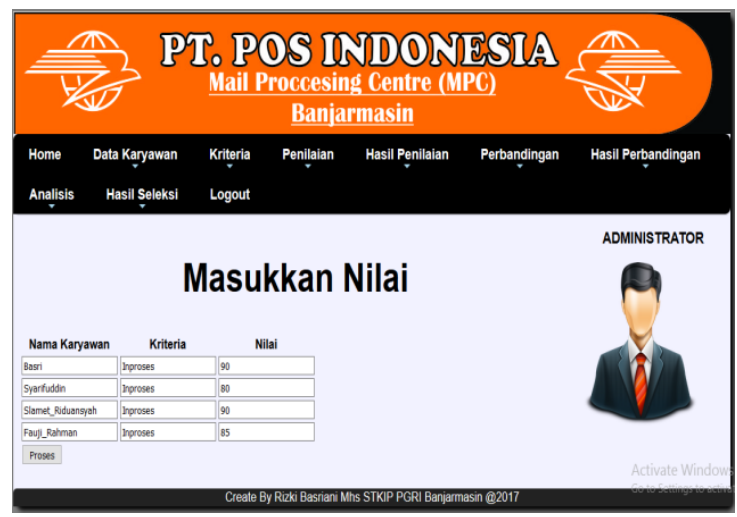

Gambar 17 Halaman Penialain

e. Halaman Perbandingan

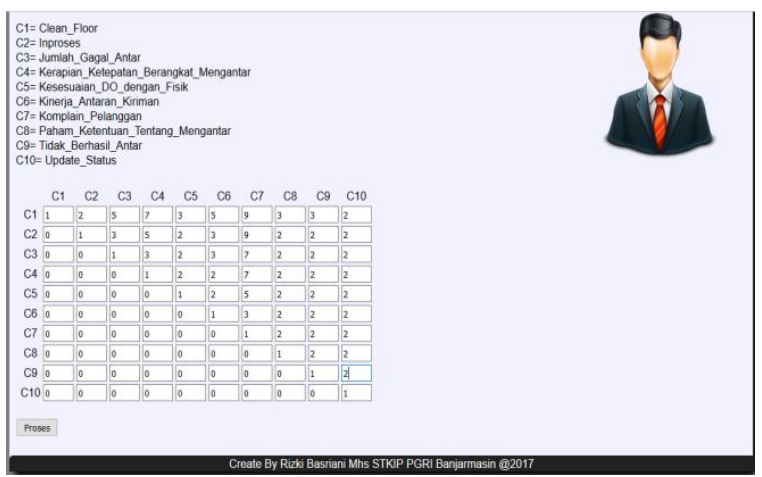

Gambar 18 Halaman Perbandingan

f. Halaman Hasil Seleksi

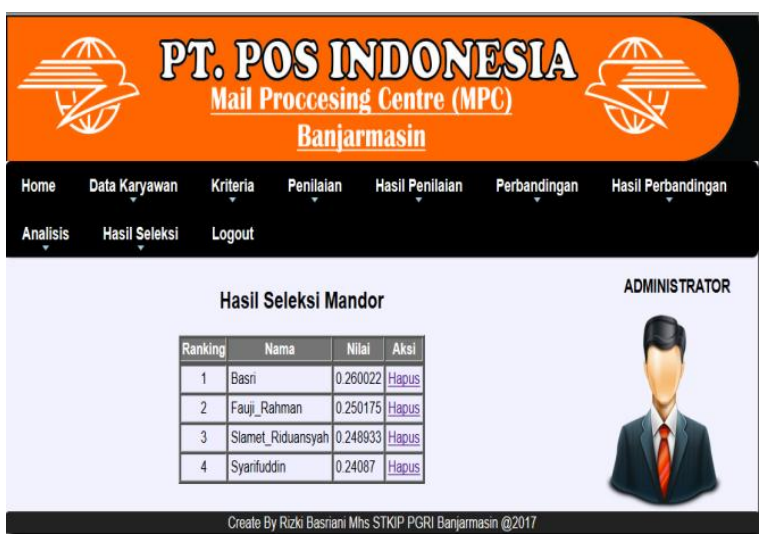

Gambar 19 Halaman Hasil Seleksi 


\section{KESIMPULAN}

Berdasarkan hasil penelitian yang diperoleh, maka dapat disimpulkan:

a. Sistem pendukung keputusan dengan metode AHP yang dibangun dapat memudahkan Manajer Antaran dalam pemilihan karyawan berprestasi Divisi Antaran di PT. Pos Indonesia MPC Banjarmasin, tanpa mengabaikan tingkat kepentingan tujuan atau kriteria.

b. Penggunaan sistem ini dapat meningkatkan efisiensi waktu.

\section{DAFTAR PUSTAKA}

Tripathi, K. P. 2011. Decision Support System is A Tool For Making Better Decisions in The Organization. Indian Journal of Computer Science and Engineering (IJCSE), 2(1), 112-117.

Saaty, T. L. 2008. Decision Making with The Analytic Hierarchy Process. Int. J. Services Sciences, 1(1): 83-98.

Kusumadewi, dkk. 2006. Fuzzy Multi-Attribute Decision Making (Fuzzy MADM). Yogyakarta: Graha Ilmu.

Alonso, J. A. dan Lamata, M. T. 2006. Consistency in The Analytic Hierarchy Process: A New Approach. Internasional Journal of Uncertainty, Fuzziness and Knowledge-Based Systems, 14(4): 445-459. 